\section{A Thirty-Year Reflection on the Value of Reference}

\author{
David C. Murray \\ David C. Murray is Humanities Librarian, The \\ College of New Jersey, Ewing, New Jersey, and \\ Chair of the History Section of RUSA.
}

Correspondence concerning this column should be addressed to Barry Trott, RUSQ Editor, 7770 Croaker Rd., Williamsburg, VA, 23188; email: btrott@wrl.org.
As RUSA is exploring how, if at all, the word "reference" succeeds in describing what its members do in the twenty-firstcentury library, it seemed an opportune moment to publish David Murray's column reflecting on reference services. I hope that this column will help us to continue the discussion of how best to describe, in a usable fashion, the complex work that public service librarians are engaged in. I would be eager to feature the work of other writers who would like to contribute to this discussion, and encourage anyone interested in writing on this topic to contact me at btrott@wrl .org. We all agree, I believe, that our work is important to our users, and the challenge is in finding a way to recognize the changes that have happened in that work without abandoning the strengths that brought us to this point. I believe that David's column is a good start to that discussion.-Editor

wrote this article in defense of reference services, broadly defined as "all the functions performed by a trained librarian ... to meet the information needs of patrons." Actions associated with these functions include advising, answering, finding, evaluating, interpreting, instructing, and promoting, among others. I am not concerned with squabbles about models employed to meet users' information needs (e.g., Should we abandon the reference desk?); implications of the corporatization of higher education for the delivery of reference services (e.g., Can we afford them?); or with zero-sum games that pit traditional services against newer ones (e.g., Must we scale back reference to support digital scholarship?). Inescapable questions all, but I wish to focus instead on the value of reference disconnected from these debates. More to the point, what would library users lose if reference services disappeared? I begin by looking backward nearly thirty years into the first chapter of my own library career to reflect on how far we have come, but more importantly to disambiguate the mutable models and tools of reference from its immutable value. I then identify two pillars of reference work unlikely to disappear no matter how much or how rapidly libraries transform. In the final section I respond to the authors of a recently published ARL report that reframed reference services as librarian-centered rather than user-centered.

In 1987, still in college and knowing very little about libraries, I applied for a part-time job paging books at the Carnegie Library of Pittsburgh (CLPgh). After three months and hundreds of trips up and down eleven flights of Edwardian-era stacks, I landed my second library job: A full-time paraprofessional position in the Telephone Ready Reference Unit (or TRRU). ${ }^{3}$ Over the next six years I honed 
my reference skills, gaining experience and knowledge that even now redound to the benefit of my patrons. In TRRU, a five-minute countdown began each time the telephone rang. If a patron's question could not be answered quickly it was transferred to a degreed reference librarian in the relevant subject department. The more disagreeable TRRU questions ranged from deadly serious to salacious. One patron I vividly recall requested the number of the nearest domestic abuse shelter. Bar bets abounded. I often hoped my proffered answer would please the tipsy, querulous patron on the other end of the line. It did not always end smoothly. Who, after all, enjoys losing a bet? Fortunately, my senior coworkers and librarian mentors trained me well. Sources consisted of a collection of several dozen classic reference books such as Lois Hutchinson's Standard Handbook for Secretaries, a lifesaver for grammar questions. Also available were the paper catalog and an index file of three-by-five cards with thenhandy tidbits such as the spellings of glasnost and perestroika. The index file I relied upon as an oracle of ephemera not otherwise retrievable. These were our tools; the bread and butter of a busy service point referred to by one patron as the "truth squad."

TRRU staff maintained an informal log of questions deemed amusing, thought provoking, or improbable. To wit: "Is the Carnegie Library of Pittsburgh open to the public?" The answer: "Yes," for nearly 100 years by 1992. In fairness, perhaps this patron resided in New York City and had become accustomed to a distinction between lending branch libraries and non-lending research libraries. It never paid to judge. Logged questions we filed under headings such as "animals," "geography," "historical anachronisms," "malapropisms," and "religion." Here are several of my favorite questions, all dating to between 1987 and 1994:

- Is Mount Rushmore natural (carved by the wind) or man-made?

- Why don't islands float, like boats?

- Did Winston Churchill discover America?

- Was General Robert E. Lee the hero of Operation Desert Storm?

- Who invented the wheel?

- Do you have a list of all the pilgrims who sailed on the Niña, Pinta, and Santa María?

- What is the address of Princess Diana, Queen of the Whales?

- Who was the last douche of Venus?

- Where do the birds go to die?

- What was the height and weight of Jesus Christ?

Ready reference, of course, epitomizes the kind of reference work devastated by users' ability to access the web. Or does it? In its first year of operation, 1977, TRRU fielded 65,891 calls. By 1996, nearly two years after the web first dominated the Internet, it handled a whopping 119,262 calls. ${ }^{4}$ By 2015 , the number of calls dropped precipitously to 27,123 , a still-healthy 8,307 (or 30.63 percent) of which consisted of reference queries. ${ }^{5}$ Rather unexpectedly, ready reference, purportedly that most outdated of reference modalities, remains relatively healthy deep into the era of Web 2.0 at the Carnegie Library of Pittsburgh and likely at other public libraries across the country.

Why, one might reasonably ask, should this be the case when searching Google is easier than calling the library? The digital divide provides one plausible answer. Too many patrons lack access to the web from home, or to a smartphone and data plan that could provide such access on the go. But the answer best fitting the data is simply that only the lowesthanging fruit has been plucked from the reference tree. "We get the questions," wrote the authors of a 2010 CLPgh report on reference staffing, "that require a more complex approach whether in context or syntax, searches requiring knowledge of the deep web, and data review requiring more than rudimentary critical thinking skills." Indeed, the definition of ready reference encapsulates how this service manages to stay relevant into the second decade of the twenty-first century. An apparently simple request, upon reflection and further inquiry, might well represent the "opening gambit" of a more complex search once the librarian understands the patron's true information need. ${ }^{7}$

The inchoate quality frequently exhibited by even the simplest reference question is apparent in the sample TRRU questions. "Why don't islands float, like boats?" cries out for a National Geographic article on island formation and plate tectonics more than a one-sentence response. The two early American history questions suggest the need to access a chronology or other reference work to straighten out basic facts related to European colonization of the Americas, but only as the first steps of a longer information journey. "Who invented the wheel?" might occasion a referral to an encyclopedia on the history of technology; even better a discussion of the nature and availability of primary sources. The answer to the question about the last doge of Venice is straightforward enough, but Google's algorithms cannot parse "douche of Venus." Try it, although perhaps not with SafeSearch turned off. Ready reference staff today utilize the open web as much or more than any other resource to assist patrons. Google is not the enemy of ready reference after all, so much as its most effective tool, not dissimilar in kind to the index file. While it might entail less effort than calling the library, Google in many instances cannot compete with a well-trained paraprofessional or reference librarian in fulfilling even users' basic information needs.

If ready reference endures, how much more pressing the obligation to prioritize robust reference services in academic libraries? Not doing so, it strikes me, constitutes an abnegation of our service commitment, and, quite frankly, crosses the line into professional malpractice. A reference question I received this semester from an undergraduate history major displays a major leap in complexity and understanding over the sample TRRU questions. "Can you help me," the student asked, "find primary sources about the practice of Western medicine in the Pamir Mountains during the Soviet era?" 


\section{FROM THE EDITOR}

The student's query elicited two counterquestions: "Do you read Russian?" and "Have you heard of the Foreign Broadcast Information Service Daily Reports?" Regardless of my initial reaction, a question this thoughtful merited a genuinely useful response. The student, in other words, deserved the opportunity to participate in a time-honored tradition in which one patron engages in meaningful interpersonal communication with one professional reference librarian, sometimes called a research consultation. At the heart of most research consultations lies a reference question. The librarian might help the student choose or refine a research topic; identify key archives and data sets; recommend relevant scholarly monographs, journal articles, and other secondary sources; pinpoint the most useful licensed abstracting and indexing databases; and brainstorm for keywords with which to effectively search the local catalog and WorldCat. The ideal location or medium by which this communication takes place might vary, but the notion that a service so vital (in both senses) might disappear from an academic library worthy of the name beggars belief.

Reference work rests on two pillars unchanged since the mid to late nineteenth century. The first is librarian as academic generalist, often also disciplinary expert, instilled with intimate knowledge of the collection and the metaknowledge required to make use of that collection. ${ }^{8}$ The second is librarian as advisor, consultant, guide, instructor, or teacher. ${ }^{9}$ How do these pillars of reference match up against the skills (not tools) required to function as a reference librarian today? RUSA President Anne Houston recently inventoried a set of seven skills employed by contemporary reference librarians: consulting and advising, teaching, interpreting, advocating, programming, user experience, and design thinking. ${ }^{10}$ While a couple undeniably "go beyond those included in traditional reference training" (e.g., programming workshops and lectures), the degree to which most remain firmly rooted within the reference tradition is striking. One might reasonably call them iterative, quite possibly additive, but not revolutionary. "The reference librarian," Houston wrote, "has always been an advisor of sorts, pointing people to the right information to meet their needs." On instruction she noted, "The role of the reference librarian is, more than ever, to teach."11 Interpreting requires "heightened interpersonal skills and an ability to communicate across an increasingly diverse population," ${ }^{12}$ expertise long common, for instance, to academic reference librarians attached to institutions located in diverse urban settings.

Minor digging revealed evidence in support of the contention that the skills utilized by today's reference librarians are not new. A striking early example comes from W. A. Jones, Librarian at Columbia College in New York in 1857:

The chief duty [of the librarian] ... is purely critical. In the performance of it, the Librarian is really an instructor, as much so as a professor, though without the title or salary. In History, civil or literary, of Philosophy or Art, in Criticism, Aesthetics, Ethical and Metaphysical Philosophy, Logic, the Evidences of Christianity, Political Economy, he necessarily comes in aid of the professor-as the Library is, as it were, an upper lecture-room for illustration and expansion of the outline designed for the classes. His business is not merely to suggest plans of reading, but actually to discuss a subject. ${ }^{13}$

Jones's crystal-clear assertion that reference work cannot be divorced from disciplinary content is a claim with which I expect most contemporary subject specialist librarians would agree. History professor Arley Barthlow Show in 1896 likewise emphasized the instructional role of the librarian before the assembled members of the Library Association of Central California: "Through instruction in the use of books and of library aids; through the personal direction of the student in his research [emphasis added]; through the freedom with which the whole resources of the library are placed at his service; and many such ways, the libraries of our colleges and universities are becoming genuine workshops."14 Perhaps to avoid any possible uncertainty as to his meaning, Show prefaced his remarks, "The librarian is truly a teacher."15 Reference work takes place across a continuum from simple (ready reference) to complex (research consultations). The "value add" of the reference librarian within this continuum comes from her ability to contextualize information for a particular audience or audiences. Deep knowledge of the collection and how to leverage it, combined with expertise in guiding users on their information journey, persist as the pillars of reference.

In 2013, Jaguszewski and Williams authored an influential report that documented changes in liaison roles at some ARL libraries. ${ }^{16}$ The authors leaned on authentic trends to articulate a fairly radical vision. But their vision for reference services is altogether evolutionary. Among surveyed ARL libraries, some liaisons have transitioned away from the reference desk toward "developing easily accessible online materials (e.g., LibGuides, screencasts)," while others are "providing more advanced one-on-one consultations with students, instructors, and researchers who need expert help." ${ }^{\prime 7}$ LibGuides and screencasts, classic aids to reference work, the authors seemed to perceive as potential replacements for the interpersonal communication between patron and librarian outlined above. Also implied, perhaps, is that these aids are novel. Of course such aids have long been a part of the reference librarian's repertoire. Comparing the function and utility of a classic pathfinder with a LibGuide, the adjective "iterative" again comes to mind. Genuinely evolved roles or skills identified in the New Roles in Research Services section of the report-supporting interdisciplinary research, implementing "expertise databases" to enhance collaboration, assisting in the management of the data lifecycle, identifying repositories of available research data - are at best additive and in no way weaken the pillars, importance, or necessity of reference services as we have understood them for well over a century. 
Reference librarians, subject specialist librarians, and liaison librarians_-pick your preferred position title-conduct neither reference transactions nor in-depth research consultations in a vacuum, or merely to satisfy some itch peculiar to that hidebound breed known as the reference librarian. Rather, in academic libraries it is the students and disciplinary faculty who have and will continue to request a broad spectrum of reference services because in them they find value. Setting aside any attachment to the reference desk, legitimate concerns remain about the impact of the vision offered by Jaguszewski and Williams on the quality of reference services delivered to students and faculty; on the ability of liaison librarians to interact serendipitously with their consitutents; and on the potential long-term repercussions for all of the other services academic libraries provide if and when reference librarians can no longer be found in libraries' public spaces.

I resisted the temptation in this article to advocate for (or to argue against) any one model employed to deliver reference services. Such discussions, or so I have observed, obfuscate more often than they illuminate. After all, models of reference and especially the tools of reference come and go, and sometimes come back. I focused instead on the fixed value of reference over time. Protestations to the contrary notwithstanding, the essential character and basic function of reference work has not changed since Samuel Swett Green popularized reference in $1876 .{ }^{18}$ Although such a statement might scandalize some in a profession whose esprit de corps centers on mastering emerging technologies, rest assured I am no Luddite. I do, however, believe that reference librarians are the inheritors of a great, Progressive-Era tradition worth preserving. Nearly three decades of experience in libraries large, medium, and small, public and academic, convinces me that patrons still need, indeed desire and in many cases demand, meaningful interactions with knowledgeable, well-trained reference librarians (or whatever name we might end up calling ourselves). Users of most libraries still retain access to high-quality reference services, but pressure to deprofessionalize reference appears to be mounting. Whether future users will benefit from such access therefore remains to be seen.

\section{References and Notes}

1. ODLIS: Online Dictionary of Library and Information Science, s.v. "reference services," accessed April 19, 2016, www.abc-clio .com/ODLIS/odlis_r.aspx.

2. Daniel Goldstein, "Library Inc.," The Chronicle of Higher Education, October 17, 2010, accessed April 25, 2016, http://chronicle com/article/Library-Inc/124915.

3. NYPL established a dedicated telephone reference department at the Mid-Manhattan Library in 1968. It inspired the Carnegie Library of Pittsburgh to establish its own Telephone Ready Reference Unit nearly ten years later. But as anyone who has watched Desk Set (1957) knows, telephone ready reference easily predates 1968.

4. Sheila Jackson, "Telephone Ready Reference Unit: Carnegie Library of Pittsburgh," accessed April 19, 2016, www.andrew .cmu.edu/user/lberard/ready.html.

5. Richard Kaplan, "Re: VR Question," email to David C. Murray, April 20, 2016.

6. Richard Kaplan and Holly McCullough, Staffing for Reference in the 21st Century (Pittsburgh, PA: Carnegie Library of Pittsburgh, 2010), accessed April 20, 2016, 2.

7. ODLIS, s.v. "ready reference," accessed April 19, 2016, www abc-clio.com/ODLIS/odlis_r.aspx.

8. Anthony Verdesca, "What's in a Word: Coming to Terms with Reference, Part Two," Reference Librarian 56, no. 3 (July-September 2015): 216, 219, http://dx.doi.org/10.1080/02763877 2015.1022849 .

9. Ibid., 220-21.

10. Anne Houston, "What's in a Name? Toward a New Definition of Reference," Reference and User Services Quarterly 55, no. 3 (Spring 2016): 186-88, http://dx.doi.org/10.5860 /rusq.55n3.186.

11. Ibid., 187

12. Ibid., 188

13. "Statement of the Librarian," in Statements, Opinions and Testimony Taken by the Committee of Inquiry, Appointed by the Trustees of Columbia College (New York: John W. Amerman, 1857): 5, accessed April 23, 2016, http://hdl.handle.net/2027 /cool.ark:/13960/t9vl2mk82.

14. Arley Barthlow Show, "The Relation of Libraries to the Higher Education," in Constitution, List of Members and Program for 1895-96 (San Francisco: California Library Association, 1897): 6-7, accessed April 27, 2016, http://hdl.handle.net/2027 /hvd.32044080306541

15. Ibid., 2 .

16. Janice M. Jaguszewski and Karen Williams, New Roles for New Times: Transforming Liaison Roles in Research Libraries (Washington, DC: Association of Research Libraries, 2013)

17. Ibid., 6

18. David A. Tyckoson, "What Is the Best Model of Reference Service?" Library Trends 50, no. 2 (Fall 2001): 186-87, 190. 